\title{
MOTIVASI DAN KONTRIBUSI PENDAPATAN USAHA KAMBING PERANAKAN ETAWA (PE) TERHADAP KELUARGA PETERNAK DI DESA KANDANGTEPUS KECAMATAN SENDURO KABUPATEN LUMAJANG
}

\author{
MOTIVATION AND CONTRIBUTION OF GOAT ETAWA (PE) BUSINESS \\ ENTERPRISES INCOME ON BREEDER'S FAMILY IN VILLAGES OF KANDANG \\ TEPUS, SUB DISTRICT OF SENDURO, DISTRICT OF LUMAJANG
}

\author{
Alfida Suwaji Florinsa1), Sudarko2), Djoko Soejono2). \\ Mahasiswa Program Studi Agribisnis Fakultas Pertanian Universitas Jember \\ Dosen Program Studi Agribisnis Fakultas Pertanian Universitas Jember \\ Email : aflorinsa@yahoo.com
}

\begin{abstract}
ABSTRAK
Susu memiliki gizi yang tinggi dan dapat digunakan sebagai makanan pendamping manusia dalam segala usia, sehingga susu merupakan makanan yang dapat dikatakan sempurna. Susu kambing peranakan etawa (PE) merupakan susu yang memiliki gizi yang sangat tinggi. Susu tidak hanya dihasilkan oleh kambing akan tetapi dapat pula dihasilkan oleh ternak lain misalnya kerbau, sapi perah, kuda dan domba. Tujuan penelitian ini untuk menentukan tingkat motivasi, faktor apa saja yang berhubungan secara signifikan dengan motivasi, pendapatan dan kontribusinya terhadap pendapatan peternak kambing peranakan etawa (PE). Penentuan daerah penelitian menggunakan purposive method. Metode penelitian yang digunakan pendekatan kuantitatif yaitu metode deskriptif dan korelasional. Analisis data menggunakan tabulasi skor, analisis korelasi Rank Spearman (rs), analisis pendapatan dan analisis statistik dengan presentase kontribusi. Hasil menunjukan bahwa tingkat motivasi tentang usaha ternak susu kambing peranakan etawa (PE) tinggi. Faktor ekstrinsik yang berkorelasi adalah kegiatan kelompok. Pendapatan peternak adalah menguntungkan. Kontribusi pendapatan usaha ternak susu kambing peranakan etawa (PE) total pendapatan keluarga peternak adalah sedang.
\end{abstract}

Kata Kunci: Susu Kambing Peranakan Etawa (PE), Motivasi, Pendapatan,dan Kontribusi

\begin{abstract}
Milk has a high nutrient and can be used as a food companion of humans in all ages, so that milk is a food that can be said perfect. Crossbred goats ettawa milk (PE) is a milk that has very high nutrients. Milk is not only produced by goats but can also be produced by other animals such as buffalo, dairy cattle, horses and sheep. The purpose of this study is to determine the level of motivation, what factors are significantly related to the motivation, income and contribution to the income of crossbred goats ettawa (PE). Determination of research area using purposive method. The research method used quantitative approach that is descriptive and correlational method. Data analysis using score tabulation, Rank Spearman correlation analysis ( $r$ s), income analysis and statistical analysis with contribution percentage. The result shows that the motivation level of goat milk peranakan etawa (PE) is high. The correlated extrinsic factor is group activity. Farmer earnings are profitable. The contribution of dairy cattle farming crossbred goats ettawa $(P E)$ to total income of breeder's family is medium.
\end{abstract}

Keywords: Goat Etawa (PE) Milk, Motivation, Income, and Contribution 


\section{PENDAHULUAN}

Susu merupakan hasil pemerahan hewan ternak yang menyusui. Susu memiliki gizi yang tinggi dan dapat digunakan sebagai makanan pendamping manusia dalam segala usia, sehingga susu merupakan makanan yang dapat dikatakan sempurna. Di negaranegara yang sudah maju maupun negaranegara yang berkembang termasuk Indonesia, masyarakatnya banyak yang sudah mengkonsumsi susu. Susu kambing peranakan etawa (PE) merupakan susu yang memiliki gizi yang sangat tinggi. Susu tidak hanya dihasilkan oleh kambing akan tetapi dapat pula dihasilkan oleh ternak lain mislanya kerbau, sapi perah, kuda dan domba.

Terdapat 12 desa di Kecamatan Senduro, hampir seluruh masyarakat disana membudidayakan kambing peranakan etawa, namun desa yang paling banyak membudidayakan kambing peranakan etawa adalah Desa Senduro, Desa Burno, Desa Pandansari, Desa Kandangtepus, Desa Kandangan dan Desa Wono Cempokoayu. Desa Kandangtepus merupakan desa yang memiliki potensi lebih besar dibandingkan dengan desa lainnya, hal ini dapat di lihat pada Tabel 1.

Tabel 1. Sebaran Jumlah Ternak Kambing Peranakan Etawa (PE) di Kecamatan Senduro Kabupaten Lumajang

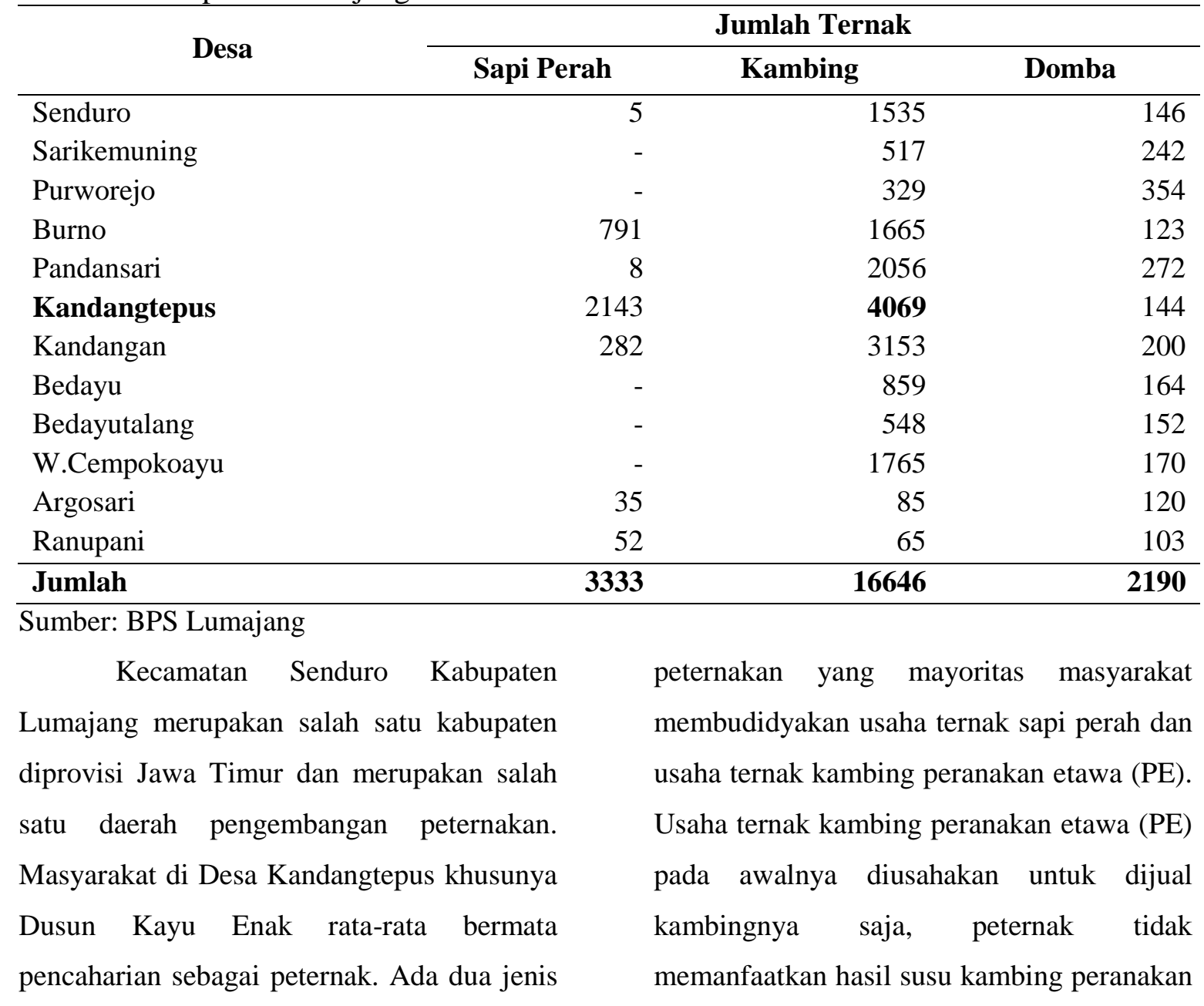


etawa (PE) untuk dijual. Sampai saat ini peternak di Desa Kandangtepus masih enggan untuk mengambil hasil susu kambing peranakan etawa dengan alasan perawatan yang dipelukan untuk pemerahan susu kambing etawa cukup menguras tenaga, oleh sebab itu peternak lebih memilih untuk menjual kambing peranakan etawa. Berdasarkan latar belakang tersebu, maka tujuan penelitian ini meliputi: untuk mengetahui tingkat motivasi peternak, faktor yang berhubungan signifikan dengan motivasi, pendapatan dan kontribusi pendapatan peternak kambing peranakan etawa di Desa Kandangtepus Kecamatan Senduro Kabupaten Lumajang.

\section{METODE PENELITIAN}

Penentuan daerah penelitian menggunakan purposive method yaitu memilih daerah penelitian secara sengaja. Penentuan daerah penelitian dipilih sesuai keadaan dan kondisi yang terdapat di lapang yang akan diteliti. Daerah penelitian yang dipilih adalah Dusun Kayu Enak Desa Kandangtepus Kecamatan Senduro Kabupaten Lumajang.

Metode penelitian yang digunakan pendekatan kuantitatif yaitu metode deskriptif dan korelasional. Metode deskriptif adalah untuk membuat deskripsi, gambaran atau lukisan secara sistematis, faktual dan akurat mengenai fakta-fakta dan sifat-sifat serta hubungan antara fenomenafenomena yang diselidiki, untuk mendapatkan kebenaran menerangkan hubungan dan menguji hipotesis sehingga memperoleh makna dan implikasi suatu masalah yang ingin dipecahkan. Metode korelasi merupakan kelanjutan dari metode deskriptif berfungsi untuk mencari hubungn diantara variabel-variabel yang diteliti (Nazir,1999).

Metode pengambilna contoh dalam penelitian ini adalah Purposive Sampling. Purposive Sampling merupakan teknik pengambilan sampel berdasarkan keperluan tertentu, dimana sampel diambil dari populasi dipilih dengan berdasarkan pertimbangan atau kriteria tertentu (Purwanto dan Sulistyastuti, 2001). Ukuran sampel dari populasi ditentukan dengan menggunakan pendapat Slovin dalam Umar (2000) yaitu dengan menggunakan formulasi, sebagai berikut:

$$
\begin{aligned}
& \mathrm{N} \\
& \mathrm{n}= \\
& 1+\mathrm{Ne} 2
\end{aligned}
$$

Keterangan:

$\mathrm{n}=$ ukuran sampel

$\mathrm{N}=$ ukuran populasi

$\mathrm{e}=$ persentase ketidaktelitian karena kesalahan pengambi-lan sampel yang masih dapat diinginkan , $15 \%$.

Berdasarkan formulasi di atas maka untuk Dusun Kayu Enak Desa Kandangtepus Kecamatan Senduro Kabupaten Lumajang. Total sampel sebesar 22 responden dari jumlah populasi peternak kambing peranakan etawa (PE) sejumlah 42 peternak kambing peranakan etawa (PE). Pemilihan sampel pada permasalahan motivasi peternak kambing peranakan etawa (PE), dilakukan dengan cara purposive sampling atau pemilihan secara sengaja berdasarkan pertimbangan tertentu (Sugiyono, 2005). Key 
Informan adalah seorang yang dianggap mengerti segala informasi di lapangan mengenai usaha ternak kambing peranakan etawa dan mengerti permasalahan yang terjadi di lapangan. Key informan yang diambil sebagai sampel penelitian adalah pihak penyuluh dari Dinas Peternakan sejumlah 1 orang.

Metode pengumpulan data menggunakan data primer adalah data yang diperoleh dengan wawancara langsung dengan responden, menggunakan kuesioner yang telah disiapkan. Data primer ini diperoleh dari peternak kambing peranakan kambing etawa (PE) Desa Kandangtepus Kecamatan Senduro, dimana data yang diperoleh dari hasil wawancara yang meliputi data identitas responden, motivasi dan pendapatan peternak yang berusaha ternak kambing peranakan etawa yang akan didapat dari responden serta data. Studi pustaka diperoleh dari instansi terkait maupun bukubuku dan penelitian yang telah dilakukan sebelumnya. Studi pustaka termasuk pada data sekunder. Data sekunder diperoleh dari Balai Desa Kandangtepus Kecamatan Senduro Kabupaten Lumajang, Dinas Peternakan Kabupaten Lumajang, Badan Pusat Statistik Kabupaten Lumajang, serta dari literatur-literatur yang terkait dengan penelitian

Metode analisis data yang digunakan dalam penelitian ini adalah Metode analisis data yang digunakan adalah metode analisis selama dilapangan dengan pendekatan analisis statistik dengan tabulasi skor, analisis korelasi Rank Spearman (rs), analisis pendapatan dan analisis statistik dengan presentase kontribusi

\section{HASIL DAN PEMBAHASAN}

\section{Tingkat Motivasi Peternak}

Motivasi adalah suatu dorongan atau kehendak yang menyebabkan seseorang melakukan suatu berbuatan untuk mencapai sutu tujuan. Dorongan berasal dari dalam maupun dari luar diri seseorang. Motivasi seseorang juga berbeda begitu pula motivasi peternak kambing peranakan etawa (PE) yang berada di Desa Kandangtepus Kecamatan Senduro Kabupaten Lumajang dalam berusaha ternak kambing peranakan etawa (PE). Peternak tidak hanya membutuhkan kebutuhan untuk keperluan sehari-hari tetapi juga membutuhkan kebutuhan keberadaan, afiliasi (memperluas pergaulan), dan kemajuan. Kebutuhankebutuhan tersebut perlu dimiliki oleh petani untuk meningkatkan semangat kerja guna menghasilkan produk usaha ternak yang lebih baik. Untuk mengetahui sejauh mana motivasi peternak dalam berusaha ternak kambing pernakan etawa (PE) dapat dilihat dalam Tabel 2 dibawah ini.

Tabel 2 Tingkat Motivasi Peternak dalam Berusaha Ternak Kambing Peranakan Etawa (PE)

\begin{tabular}{lrlrr}
\hline $\begin{array}{c}\text { N } \\
\mathbf{0}\end{array}$ & Skor & $\begin{array}{c}\text { Motivas } \\
\mathbf{i}\end{array}$ & $\begin{array}{c}\text { Jumla } \\
\text { h } \\
(\text { Oran } \\
\text { g) }\end{array}$ & $\begin{array}{c}\text { Persenta } \\
\text { se (\%) }\end{array}$ \\
\hline 1 & $\begin{array}{c}51- \\
58\end{array}$ & Rendah & 0 & 0 \\
2 & $\begin{array}{c}59- \\
66\end{array}$ & Tinggi & 22 & 100 \\
\hline & & Jumlah & $\mathbf{2 2}$ & $\mathbf{1 0 0}$ \\
\hline
\end{tabular}

Sumber: Data Primer Diolah 


\section{Tingkat Kebutuhan Keberadaan}

Kebutuhan akan keberadaan merupakan kebutuhan yang berhubungan dengan kebutuhan dasar peternak kambing peranakan etawa (PE). Kebutuhan dasar tersebut meliputi sandang, pangan, papan, pendidikan, hiburan, kesehatan dan rasa aman. Responden memiliki tingkat motivasi yang cukup tinggi dilihat dari kebutuhan akan keberadaan. Kebutuhan akan keberadaan merupakan kebutuhan dasar yang harus dipenuhi oleh peternak, karena mencakup kebutuhan utama seperti sandang, pangan, papan, pendidikan, hiburan, kesehatan dan rasa aman. Dengan melalakukan usaha ternak peternak mampu memenuhi kebutuhan pangan dengan makanan-makanan yang bergizi, selain itu peternak juga memberikan makan ekstra kepada keluarga mereka, walaupun tidak semua peternak menyatakan tidak selalu ada makanan esktra pada menu makanan responden.

Hasil penelitian menunjukkan bahwa dengan berusaha ternak kambing peranakan etawa (PE) kebutuhan akan sandang yang nyaman dan layak mampu dipenuhi oleh para peternak kambing peranakan etawa (PE). Kebutuhan sandang bagi para peternak kambing peranakan etawa (PE) merupakan kebutuhan yang cukup penting, tidak hanya jumlah baju yang dimiliki namun mencakup keinginan untuk memiliki baju yang layak dan nyaman juga merupakan kebutuhan pokok. Keluarga peternak menggunakna pakaian yang layak tidak hanya dihari lebaran dan hari-hari besar lainnya, namun setiap hari menggunakan pakaian yang layak dan sesuai dengan keinginan peternak.

\section{Tingkat Kebutuhan Afiliasi}

Kebutuhan akan afiliasi merupakan kebutuhan yang diperlukan untuk kelancaran proses usaha ternak dengan cara menjalin hubungan baik dengan peternak kambing etawa (PE) lain, ketersediaan sumber informasi peternakan, bertukar informasi dengan peternak lain, bergabung dengan kelompok dan keikutsertaan petani pada setiap kegiatan kelompok.

Seluruh peternak responden memiliki tingkat motivasi yang tinggi, hasil lapang menyatakan bahwa peternak bergabung dengan kelompok dan menjalin hubungan yang baik dengan peternakpeternak yang lain. Peternak mendapatkan keuntungan saat mejadi anggota kelompok karena dengan para peternak bergabung dengan kelompok mereka mendapatkan kemudahan-kemudahan dalam hal usaha ternak kambing peranakan etawa (PE).

Mayoritas peternak menyatakan sumber informasi yang mereka peroleh mengenai usaha ternak kambing peranakan etawa (PE) seperti sektor pasar, harga dan asupan vitamin. Adanya pengarahan dari Dinas Peternakan Kabupaten Lumajang yang memberikan informasi-informasi dan pengetahuan-pengetahuan mengenai peternakan kepada para peternak akan menambah wawasan informasi dan pengetahuan. 


\section{Tingkat Kebutuhan Kemajuan}

Kebutuhan akan kemajuan bagi para peternak kambing peranakan etawa (PE) seperti meningkatkan produksi susu kambing peranakan etawa (PE), mengembangkan usaha ternak kambing peranakan etawa (PE) dan menambah pengetahuan tentang ternak kambing peranakan etawa (PE).

Seluruh responden memiliki tingkat motivasi yang cukup tinggi, dapat dilihat dari indikator tingkat kebutuhan kemajuan. Hasil penelitian menunjukkan bahwa peternak antusias ingin meningkatkan usaha ternak kambing peranakan etawa (PE) supaya produksi meningkat. Mayoritas peternak menyatakan bahwa hasil usaha ternak kambing peranakan etawa (PE) sudah cukup menguntungkan. Usaha ternak kambing peranakan etawa (PE) lebih potensial dibandingkan dengan usaha lainnya, dengan produktifitas yang cukup tinggi dengan ratarata pendapatan yang diperoleh oleh para petermak sebesar Rp. 1.108.085 selama satu bulan. Dengan rata-rata pendapatan yang diperoleh peternak mengungkapkan semakin kedepan semakin semangat untuk berusaha ternak kambing peranakan etawa.

Responden mengungkapkan selalu berusaha untuk mencari informasi dan mengembangkan pengetahuan baru tentang berusaha ternak kambing peranakan etawa (PE). Dengan ada sarana dan prasana yang sudah sangat mendukung kegiatan usaha ternak, peternak semakin semangat untuk mengembangkan usaha. Seluruh peternak menyatakan bahwa sarana transportasi yang ada saat ini sudah sangat memadai, kondisi jalan yang cukup lebar dan bagus sudah dapat dilewati kendaraan-kendaraan umum maupun pribadi. Sehingga memudahkan peternak untuk membawa hasil susu kambing kambing mereka kepada konsumenkonsumen.

\section{Faktor-Faktor yang Berhubungan dengan Motivasi Peternak}

Motivasi peternak berusaha ternak kambing peranakan etawa (PE) di Desa Kandangtepus oleh beberapa faktor intrinsik dan ekstrinsik. Faktor-faktor intrinsik yang berhubungan dengan motivasi peternak kambing pernakan etawa (PE) adalah umur, pengalaman, jumlah anggota keluarga, dan lama pendidikan. Sedangkan untuk faktorfaktor ekstrinsik yang berhubungan dengan motivasi peternak kambing peranakan etawa (PE) yaitu lingkungan sosial, lingkungan ekonomi dan kegiatan kelompok. Faktorfaktor tersebut dianalisis dengan menggunakan analisis Rank Spearman. Analisis tersebut berfungsi untuk mengetahui sejauh mana kedua variabel tersebut berhubungan. Berikut penjelasan pada masing-masing faktor:

\section{Faktor Intrinsik dan Faktor Ekstrinsik yang Berhubungan dengan Motivasi Peternak}

Tingkat motivasi peternak kambing peranakan etawa (PE) yang ada di Dusun Kayu Enak Desa Kandangtepus Kecamatan Senduro dipengaruhi oleh beberapa faktor. Faktor-faktor tersebut meliputi faktor intrinsik dan faktor ekstrinsik. Faktor 
intrinsik meliputi umur, pengalaman, jumlah anggota keluarga dan tingkat pendidikan, sedangkan faktor ekstrinsik meliputi lingkungan sosial, lingkungan ekonomi dan kegiatan kelompok. Hasil analisis Rank
Spearman (rs) faktor intrinsik dan faktor ekstrinsik yang berhubungan dengan motivasi peternak berusaha ternak kambing peranakan etawa (PE) dapat dilihat pada Tabel 3 di bawah ini.

Tabel 3 Hubungan Faktor Intrinsik dan Ekstrinsik terhadap Motivasi Peternak dalam Berusaha Ternak Kambing Peranakan Etawa (PE)

\begin{tabular}{|c|c|c|}
\hline $\begin{array}{c}\text { Faktor intrinsik dan Faktor } \\
\text { Ekstrinsik }\end{array}$ & Signifikansi & rs hitung \\
\hline Umur peternak & 0.914 & 0.025 \\
\hline Pengalaman Peternak & 0.908 & -0.026 \\
\hline Jumlah Aggota Keluarga (JAK) & 0.400 & -0.189 \\
\hline Tingkat Pendidikan & 0.924 & 0.022 \\
\hline Lingkungan sosial & 0.820 & 0.051 \\
\hline Lingkungan ekonomi & 0.477 & -0.160 \\
\hline Kegiatan kelompok & 0.015 & -0.513 \\
\hline
\end{tabular}

Sumber: Data Primer Diolah

Berdasarakan hasil analisis Rank Spearman (rs) padat Tabel 5.6, dapat dijelaskan bahwa hasil pengujian hubungan masing-masing variabel terhadap motivasi peternak berusaha ternak kambing peranakan etawa (PE) di Desa Kandangtepus Kecamatan Senduro Kabupaten Lumajang adalah sebagai berikut:

\section{- Umur Peternak}

Hasil perhitungan menunjukkan koefisien korelasi Rank Spearman didapakan nilai rs-hitung sebesar 0,025 nilai tersebut kurang dari 0,05. Nilai probabilitas pada taraf kepercayaan $95 \%$ sebesar 0.914 nilai tersebut lebih dari 0.05 artinya tidak ada korelasi umur dengan tingkat motivasi peternak dalam berusaha ternak kambing peranakan etawa (PE). Hasil dilapang menunjukkan bawa peternak dalam berusaha ternak tidak memandang usia. Keseluruhan usia peternak yang berusaha ternak kambing peranakan etawa (PE) di Desa Kandangtepus adalah termasuk usia produktif, dimana usia produktif adalah usia antara 15 - 64 tahun. Usia paling muda yang dimiliki peternak kambing peranakan etawa (PE) adalah 32 tahun dan yang paling tua adalah 60 tahun. Usia peternak mempengaruhi motivasi dalam melakukan usaha ternak kambing perankan etawa (PE). Batoa et al (2008), menyatakan bahwa petani yang lebih muda dan sehat memiliki kemampuan fisik yang lebih besar jika dibandingkan dengan petani yang lebih tua. Peternak yang berumur muda lebih tanggap dalam menerima proses adopsi inovasi dan sebaliknya peternak yang berusia lebih tua mempunyai sifat kehati-hatian dan penuh pertimbangan dalam menerima suatu inovasi baru. Sehingga hipotesis yang diajukan ditolak yang artinya tidak terdapat korelasi yang signifikan antara faktor 
intrinsik usia peternak dengan motivasi peternak kambing peranakan etawa (PE).

- $\quad$ Pengalaman Peternak

Hasil perhitungan menunjukkan koefisien korelasi Rank Spearman (rs) didapat nilai rs-hitung sebesar $-0,026$. Nilai probabilitas atau signifikansi pada taraf kepercayaan 95\% sebesar 0.908 nilai tersebut lebih dari 0,05 artinya tidak ada korelasi yang signifikan antara pengalaman dengan tingkat motivasi pengalaman motivasi peternak berusaha ternak kambing pernakan etawa (PE), sehingga hipotesis yang diajukan ditolak. Pengalaman yang dimiliki oleh peternak dalam berusaha ternak kambing peranakan etawa (PE) paling sedikit 5 tahun dan 26 tahun adalah pengalaman yang paling banyak. Pengalaman 5 tahun bukan waktu yang lama bagi para peternak beusaha ternak. Hal tersebut dikarenakan para peternak masih harus belajar bagaimana berusaha ternak yang baik dan bisa mendapatkan produksi susu kambing yang sesuai dengan harapan. Rata-rata pengalaman 5 tahun mengusahakan kambing peranakan etawa menunjukkan bahwa pengalaman tidak mempengaruhi motivasi peternak dalam berusaha ternak kambing peranakan etawa, keinginan memenuhi kebutuhan keluarga merupakan tujuan utama bagi para peternak.

- Jumlah Anggota Keluarga (JAK)

Hasil perhitungan menunjuukan koefien korelasi Rank Spearman (rs) didapatkan nilai $-0,183$. Nilai probabilitas atau signifikansi pada taraf kepercayaan 95\% sebesar 0,400. Nilai probailitas tersebut lebih dari 0,05 , sehingga hipotesis yang diajukan ditolak artinya tidak terdapat korelasi yang signifikan antara faktor intrinsik jumlah anggota keluarga peternak dengan motivasi peternak dalam berusaha ternak kambing peranakan etawa (PE). Nilai negatif menunjukkan bahwa tidak ada hubungan yang searah, sehingga dapat disimpulkan bahwa semakin sedikit jumlah anggota keluarga peternak mempunyai kecenderungan motivasi yang rendah, sebaliknya semakin banyak jumlah anggota keluarga yang ditanggung peternak maka semakin tinggi pula motivasinya.

Hasil lapang menunjukkan jumlah tanggungan keluarga merupakan salah satu faktor yang mampu memotivasi peternak dalam berusaha terank kambing peranakan etawa (PE). Semakin banyak jumlah tanggungan keluarga maka semakin banyak pula kebutuhan hidup sehari-hari yang harus terpenuhi oleh peternak. Jumlah anggota keluarga yang menjadi tanggungan peternak kambing peranakan etawa (PE) paling sedikit sebanyak 3 orang dan paling banyak 6 orang. Jumlah anggota keluarga yang menjadi tanggungan keluarga dapat memberikan semangat untuk peternak dapat bekerja lebih baik. Dengan berusaha ternak kambing peranakan etawa (PE) kebutuhan keluarga akan terpenuhi. Pendapatan yang besar mampu memotivasi peternak untuk terus berusaha ternak kambing peranakan etawa (PE) karena pendapatan yang diperoleh akan digunakan untuk memenuhi kebutuhan hidup keluarga dengan baik.

- $\quad$ Tingkat Pendidikan 
Hasil perhitungan koefisien korelasi Rank spearman (rs) menunjukkan bahwa nilai rs-hitung tingkat pendidikan sebesar 0.022. Nilai probabilitas pada taraf kepercayaan $95 \%$ sebesar 0.924 nilai tersebut lebih dai 0,05 sehingga hipotesis yang diajukan ditolak artinya tidak ada korelasi yang signifikan antara tingkat pendidikan dengan tingkat motivasi peternak dalam berusaha ternak kambing peranakan etawa (PE). Hasil lapang menunjukkan bahwa peternak tidak memandang pendidikan formal dalam berusaha ternak. Pendidikan formal peternak beragam mulai Sekolah Dasar (SD) sampai dengan Sekolah Menengah Atas (SMA), mayoritas pendidikan peternak responden adalah Sekolah Dasar (SD). Semakin tinggi atau rendah pendidikan formal bagi peternak tidak berpengaruh terhadap motivasi dalam berusaha ternak kambing peranakan etawa. Para peternak memperoleh pengalaman atau cara berusaha ternak dari keluarga, teman dan tetangga yang sudah terlebih dahulu berusaha ternak kambing peranakan etawa (PE). Peternak akan selalu berusaha untuk dapat meningkatkan hasil produksi susu kambing peranakan etawa (PE) dengan selalu bertukar informasi dengan peternak lainnya. Hal ini berarti keterampilan yang diperoleh peternak berasal dari luar bangku sekolah.

\section{- $\quad$ Lingkungan Sosial}

Hasil perhitungan koefisien korelasi Rank Spearman (rs) menunjukkan bahwa nilai rs-hitung lingkungan sosial sebesar 0,051. Nilai probabilitas pada taraf kepercayaan $95 \%$ sebesar 0,820 . Nilai tersebut lebih dari 0,05 , sehingga hipotesis yang diajukan ditolak artinya tidak ada korelasi yang signifikan antara lingkungan sosial dengan tingkat motivasi peternak dalam berusaha ternak kambing peranakan etawa (PE). Hasil lapang menunjukkan bahwa anggota keluarga dan lingkungan masyarakat sekitar mendukung peternak untuk melakukan kegiatan usaha ternak kambing peranakan etawa (PE) karena dengan adanya usaha ternak kambing peranakan etawa $(\mathrm{PE})$ pendapatan keluarga mereka bertambah, sehingga dukungan dari keluarga semakin memotivasi peternak untuk melakukan kegiatan usaha ternak. Adanya limbah yang dihasilkan dari usaha ternak seperti (kotoran ternak) dimanfaatkan kembali sebagai pupuk alami untuk pertanian oleh peternak dan ranting-ranting kayu pakan hijau dimanfaatkan untuk kayu bakar. Namun ada beberapa peternak mengaku bahwa dilingkungan mereka kurang mendukung sebab kandang kambing terlalu dekat dengan pemukiman, sehingga limbah (kotoran ternak) dari kambing etawa tercium oleh warga disekitar kandang.

\section{- $\quad$ Lingkungan ekonomi}

Hasil perhitungan koefiensi korelasi Rank Spearman (rs) menunjukkan bahwa nilai rs-hitung lingkungan ekonomi sebesar 0,160. Nilai probabilitas pada taraf kepercayaan $95 \%$ sebesar 0,477 . Nilai tersebut lebih dari 0,05 sehingga hipotesis yang diajukan ditolak artinya tidak ada korelasi yang signifikan antara lingkungan ekonomi dan tingkat motivasi peternak dalam berusaha ternak kambing peranakan 
etawa (PE). Rata-rata keseluruhan peternak responden menyatakan bahwa ketersediaan pakan hijauan (daun sengon dan kaliandra), pakan konsentrat atau pakan tambahan dan bibit kambing cukup terpenuhi dengan baik. Wilayah Desa Kandangtepus terutama wilayah Kayu Enak banyak terdapat pakan hijauan. Meskipun di wilayah tersebut terdapat banyak pakan hijauan para peternak harus membeli pakan hijauan tersebut dengan harga Rp. 1000/kg. Untuk konsentrat atau pakan tambahan para peternak menggunakan tumpi dan ampas singkong keduanya memiliki peran yang cukup mendukung proses produksi susu kambing peranakan etawa.

\section{Kegiatan Kelompok}

Hasil perhitungan koefisiensi korelasi Rank Spearman (rs) nilai rs-hitung kegiatan kelompok sebesar -0.513. Nilai probabilitas pada taraf kepercayaan 95\% sebesar 0,015. Nilai tersebut kurang dari 0,05 sehingga hipotesis yang diajukan diterima, artinya ada korelasi yang signifikan antara kegiatan kelompok dengan tingkat motivasi peternak dalam berusaha ternak kambing peranakan etawa (PE). Hasil lapang menunjukkan moyaritas peternak menyatakan bahwa peternak bergabung dalam kelompok namun tidak semua peternak ikut serta dalam aktivitas tersebut karena kegiatan yang terdapat pada kelompok hanya sekedar arisan atau kumpulkumpul saja. Sedikit banyaknya kegiatan kelompok tidak berpengaruh terhadap keberlangsungan usaha ternak kambing pernakan etawa (PE).

\section{Pendapatan Peternak Kambing Peranakan Etawa (PE)}

Tabel 4 Rata-Rata Produksi, harga jual, total biaya, penerimaan dan pendapatan pada usaha ternak Kambing Peranakan Etawa (PE) di Desa Kandangtepus Kecamatan Senduro Kabupaten Lumajang

\begin{tabular}{|c|c|c|c|}
\hline No & Uraian & Satuan & Nilai \\
\hline 1 & Rata-rata produksi $(\mathrm{Q})$ & L / Peternak/ bulan & 313 \\
\hline 2 & Rata-rata harga jual (P) & $\mathrm{Rp} / \mathrm{L}$ & 10.545 \\
\hline \multirow[t]{13}{*}{3} & $\bullet \quad$ Rata-rata penyusutan bibit & Rp / bulan & 278.598 \\
\hline & - $\quad$ Rata-rata penyusutan kandang & Rp / bulan & 100.002 \\
\hline & Rata-rata penyusutan milk can & Rp / bulan & 6.689 \\
\hline & Rata-rata biaya literan & Rp / bulan & 2.434 \\
\hline & Rata-rata penyusutan lemari es & Rp / bulan & 52.020 \\
\hline & Rata-rata biaya tetap (TFC) & Rp / bulan & 413.733 \\
\hline & Rata-rata biaya pakan hijau & Rp / bulan & 442.773 \\
\hline & Rata-rata biaya pakan konsentrat & $\mathrm{Rp} /$ bulan & 9.591 \\
\hline & Rata-rata biaya botol & Rp / bulan & 4.178 \\
\hline & Rata-rata biaya lain-lain & Rp / bulan & 59.910 \\
\hline & Rata-rata biaya TK & Rp / bulan & 1.315 .909 \\
\hline & Rata-rata biaya variabel (TVC) & Rp / bulan & 1.779 .592 \\
\hline & - $\quad$ Rata-rata total biaya (TFC + TVC) & Rp / bulan & 2.213 .324 \\
\hline 4 & Rata-rata penerimaan $(\mathrm{Q} \times \mathrm{P})$ & Rp / bulan & 3.321 .409 \\
\hline 5 & Rata-rata Pendapatan (TR - TC) & Rp / bulan & 1.108 .085 \\
\hline
\end{tabular}

Sumber: Data Primer Diolah 
Berdasarkan tabel 4 terlihat bahwa rata-rata produksi susu kambing yaitu sebesar 313 liter, dengan rata-rata kepemilikan kambing 9 ekor. Rata-rata biaya variabel usaha ternak susu kambing peranakan etawa (PE) yaitu sebesar $\mathrm{Rp}$. 1.799.592/bulan, yang terdiri dari biaya pakan hijau, pakan konsentrat, biaya botol, biaya lain-lain (biaya pembelian obat, vitamin dan dokter hewan), dan tenaga kerja.

Biaya produksi terbesar yang dikeluarkan oleh peternak pada tahun 2016 terletak pada biaya tenaga kerja yaitu sebesar Rp. 1.315.909/bulan. Rata-rata tenaga kerja yang diguakan selama kegiatan usaha ternak ialah 1 orang dari luar keluarga dan 1 orang dari dalam keluarga dengan satu hari kerja yaitu 8 jam kerja. Tenaga kerja yang digunakan kebanyakan tenaga kerja dari luar anggota keluarga. Pekerjaan yang dilakukan yaitu memerah susu, memberikan pakan, mencari pakan hijau dan membersihkan kandang.

Biaya produksi terbesar kedua yaitu biaya pakan hijauan yaitu sebesar Rp. 442.773/bulan. Pakan hijauan ini merupakan makanan pokok ternak untuk dapat menghasilkan susu dalam jumlah maksimal. Semakin banyak jumlah ternak semakin banyak pula kebutuhan akan pakan hijauan. Harga pakan hijuan Rp. 1000. Pakan hijauan yang diberikan pada kambing peranakan etawa (PE) yaitu albasia dan kaliandra. Satu kambing peranakan etawa (PE) dalam satu hari menghabiskan pakan hijau sebanyak 1 $2 \mathrm{~kg}$. Pemberian pakan hijauan ini diberikan dua kali dalam satu hari yaitu pagi pada pukul 07.00 WIB dan sore pada pukul 15.00 WIB. Biaya akan pakan hijauan ini sangat besar karena kebutuhan akan pakan hijauan ini juga sangat besar untuk merangsang pertumbuhan kambing khususnya pada kambing usia produktif yaitu pada usia 1,5 3,5 tahun.

Biaya ketiga terbesar yaitu biaya lain-lain sebesar Rp. 59.910/bulan, yaitu terdiri dari biaya pembelian obat, pembelian vitamin, dan dokter hewan. Kemudian biaya konsentrat sebesar Rp. 9.591/bulan. Pakan konsentrat ini memiliki banyak sumber protein sehingga kambing dapat menghasilkan produksi susu dalam jumlah yang banyak dan untuk menambah pertambahan bobot ternak. Pakan konsentrat merupakan pakan yang digunakan bersama pakan lainnya dan dicampur sebagai pakan pelengkap untuk meningkatkan keserasian gizi. Konsentrat yang digunakan yaitu terdiri dari ampas singkong dan tumpi jagung. Tumpi jagung merupakan limbah agroindustri pemipilan jagung yang mengandung protein untuk pakan ternak. Ampas singkong dan tumpi ini harus dihaluskan terlebih dahulu supaya mudah untuk diperah oleh ternak dan kemudian dicampur menjadi satu. Biaya terakhir adalah biaya pembelian botol yaitu sebesar Rp. 5.855/bulan yang digunakan untuk pengemasan susu kambing.

Biaya tetap dalam penelitian ini adalah penyusutan bibit, penyusutan kandang, biaya penyusutan milk can, biaya penyusutan literan, dan biaya penyusutan lemari es. Rata-rata biaya tetap yaitu sebesar 
Rp. 413.857/bulan. Dapat diketahui rata-rata produksi yaitu 313 liter dengan rata-rata harga susu sebesar Rp. 10.545/ liter. Jadi rata-rata penerimaan yang diterima oleh peternak susu kambing peranakan etawa di Desa Kandangtepus Kecamatan Senduro sebesar Rp. 3.300.585/bulan dengan rata-rata total biaya Rp. 2.213.324/bulan, di peroleh rata-rata pendapatan sebesar Rp. 1.108.085/bulan. Berdasarkan hasil tersebut menjelaskan bahwa usaha ternak susu kaming perankaan etawa (PE) menguntungkan bagi peternak, artinya TR > TC. Hal ini meunjukkan bahwa hipotesis ketiga diterima.

\section{Kontribusi Pendapatan Usaha Ternak Kambing Peranakan Etawa (PE) Terhadap Pendapatan Keluarga}

Tabel 5 Kontribusi Pendapatan Usaha Ternak Kambing Peranakan Etawa Terhadap Total Keluarga Peternak

\begin{tabular}{lr}
\hline Keterangan & Nilai \\
\hline Rata-rata pendapatan usahaternak kambing etawa & 3.321 .409 \\
Rata-rata pendapatan usahatani & 512.135 \\
Rata-rata pendapatan berdagang & 548.864 \\
Rata-rata pendapatan non kambing etawa (buruh bangunan) & 1.950 .000 \\
Rata-rata pendapatan non usahaternak (pegawai KUD) & 3.500 .000 \\
Rata-rata pendapatan anggota keluarga & 1.244 .000 \\
Total pendapatan keluarga & 5.268 .807 \\
\hline Kontribusi Pendapatan Usaha ternak Kambing & $\mathbf{6 3 \%}$ \\
\hline
\end{tabular}

Sumber: Data Primer Diolah

Berdasarkan tabel 5 dapat ditunjukkan bahawa rata-rata kontribusi pendaptan usaha ternak kambing peranakan etawa (PE) di Desa Kandangtepus Kecamatan Senduro Kabupaten Lumajang terhadap pendapatan total keluarga selama satu bulan sebesar 63\%. Nilai tersebut diperoleh dari perbandingan antara rata-rata pendapatan dari usaha ternak kambing peranakan etawa (PE) sebesar Rp. 3.321.409,- dengan rata-rata pendapatan total keluarga Rp. 5.268.807,-. Nilai kontribusi pendapatan usaha ternak terbilang sedang karena selain berusaha ternak para peternak juga berusahatani seperti menanam pisang, kopi, wortel, kubis dan ubi/talas. Dengan lahan yang peternak miliki peternak memanfaatkan lahan tersebut untuk menambah penghasilan para peternak. Ratarata pendapatan berdagang di Desa Kandangtepus terhadap pendapatan total keluarga sebesar 10\%. Nilai tersebut diperoleh dari perbandingan antara rata-rata pendapatan berdagang sebesar Rp. 546.864,dengan pendapatan total keluarga sebesar Rp. 5.278.807,-. $\quad$ Nilai kontribusi tersebut dikategorikan sedang karena mayoritas responden bermata pencaharian sebagai peternak. Rata-rata pendapatan lain-lain yaitu sebagai kuli bangunan di Desa Kandangtepus 
terhadap pendapatan keluarga sebesar $37 \%$.

Nilai tersebut diperoleh dari perbandingan antara rata-rata pendapatan lain-lain sebesar Rp. 1.950.000,- dengan pendapatan total keluarga sebesar Rp. 5.278.807,-. Pendapatan tersebut dikategorikan sedang, melihat dari keseluruhan responden hanya satu responden yang memiliki pendapatan non usaha ternak (buruh bangunan). Rata-rata kontribusi pendapatan anggota keluarga peternak kambing peranakan etawa (PE) terhadap pendapatan keluarga sebsar $21 \%$. Nilai tersebut diperoleh dari perbandingan antara rata-rata pendapatan anggota keluarga sebesar Rp. 1.244.000,- dengan pedapatan total keluarga sebesar Rp. 5.268.807,-Pendapatan anggota keluarga ini berasal dari pendapatan istri peternak yang bekerja sebagai penjual makanan ringan di sekolahsekolah maupun dirumah dan pendapatan anak peternak yang bekerja menjadi karyawan di pabrik-pabrik kayu di wilayah Lumajang dan penjaga toko dipasar.

Berdasarkan kriteria pengambilan keputusan yaitu jika kontribusi pendapatan usahaternak kambing peranakan etawa (PE) $<25 \%$ dari pendapatan total keluarga peternak kambing peranakan etawa (PE) maka kontribusi pendapatan dikategorikan sangat rendah, jika kontribusi pendapatan usaha ternak kambing peranakan etawa (PE) $35 \%$ - $70 \%$ dari pendapatan total keluarga peternak kambing peranakan etawa (PE) maka kontribusi pendapatan dikategorikan sedang, dan jika kontribusi pendapatan usaha ternak kambing peranakan etawa $(\mathrm{PE})>75 \%$ dari total pendapatan keluarga peternak kambing peranakan etawa (PE) maka kontribusi pendapatan dikategorikan sangat tinggi. Dalam penelitian ini dapat disimpulkan bahwa rata-rata kontribusi pendapatan usaha ternak kambing peranakan etawa (PE) di Desa Kandangtepus termasuk dalam kategori sedang dapat dilihat nilai kontribusinya sebesar $63 \%$, dari pendapatan total keluarga peternak kambing peranakan etawa (PE). Hipotesis keempat yang diajukan bahwa kontribusi usaha ternak kambing peranakan etawa (PE) terhadap pendapatan total keluarga di Desa Kandangtepus adalah tinggi ditolak, hal tersebut dilihat dari kontribusi pendapatan usaha ternak kambing peranakan etawa (PE) $35 \% \leq Z \leq 70 \%$.

\section{KESIMPULAN}

- $\quad$ Tingkat motivasi tentang usaha ternak susu kambing peranakan etawa (PE) di Desa Kandangtepus Kecamatan Senduro Kabupaten Lumajang termasuk dalam kategori tinggi.

- Faktor ekstrinsik yang berkorelasi dengan motivasi peternak dalam berusaha ternak kambing peranakan etawa (PE) adalah kegiatan kelompok ditunjukkan dengan nilai korelasi sebesar 0,015.

- $\quad$ Rata-rata pendapatan peternak susu kambing peranakan etawa sebesar Rp. 1.108.085/bulan dengan rata-rata populasi kambing peranakan etawa (PE) adalah 9 ekor. Penerimaan 
peternak susu kambing peranakan etawa (PE) sebesar Rp. 3.300.585/bulan dengan total biaya yang dikeluarkan adalah sebesar Rp. 1.799.592/bulan, sehingga dapat bahwa usaha ternak susu kambing peranakan etawa (PE) adalah menguntungkan.

- Kontribusi pendapatan usaha ternak susu kambing peranakan etawa (PE) di Desa Kandangtepus Kecamatan Senduro Kabupaten Lumajang terhadap total pendapatan keluarga. peternak adalah sedang (pendapatan total total keluarga yaitu sebesar 63\%).

\section{DAFTAR PUSTAKA}

Batoa. et al. 2008. Faktor-Faktor Yang Berhubungan Dengan Kopetensi Petani Rumput Laut Di Kabupaten Konawe Provinsi Sulawesi Tenggara [serial on line] http://repository.ipb.ac.id. [20 Agustus 2016]

Nazir, Moh. 1999. Metode penelitian, Jakarta: Ghalia Indonesia

Purwanto., Erwan Agus dan Dyah Ratih Sulistyastuti. 2001. Metode Penelitian Kuantitatif. Yogyakarta: Gava Media

Sugiyono. 2005. Metode penelitian administrasi. Bandung : Alfabeta

Umar, H. 2000. Metodologi Penelitian : Aplikasi dalam Pemasaran. Jakarta: Gramedia Pustaka Utama. 